ISSN 0258-7122

Bangladesh J. Agril. Res. 38(3): 467-472, September 2013

\title{
MICROPROPAGATION OF STRAWBERRY (Fragaria ananassa) THROUGH RUNNER CULTURE
}

\author{
M. ASHRAFUZZAMAN ${ }^{1}$, S. M. FAISAL ${ }^{2}$, D. YADAV $^{3}$ \\ D. KHANAM ${ }^{4}$ AND F. RAIHAN ${ }^{5}$
}

\begin{abstract}
In vitro propagation of strawberry was conducted at the Biotechnology Lab. of BARI, Joydebpur, Gazipur. For shoot induction, five BAP concentrations viz., 0.0 (Control), 0.5, 1.0, 1.5, and $2.0 \mathrm{mg} / \mathrm{l}$ and for root induction four IBA concentrations viz., 0.0 (Control), $0.5,1.0$, and $1.5 \mathrm{mg} / \mathrm{l}$ were used. The highest average number of shoots (7) and the highest average length $(3.34 \mathrm{~cm})$ of shoot was observed at the concentration of $0.5 \mathrm{mg} / \mathrm{l} \mathrm{BAP}$. The highest average number of leaves (5) was also observed at the same concentration. Among the five rooting concentrations, IBA @ $0.5 \mathrm{mg} / \mathrm{l}$ showed the best performance in all the parameters studied. The highest number (6) of roots/culture and the longest $(3.05 \mathrm{~cm})$ roots were also obtained from this concentration. Half strength MS media without IBA concentration did not show any response regarding root induction.
\end{abstract}

Keywords: Proliferation, micropropagation, strawberry, inoculation.

\section{Introduction}

Strawberry (Fragaria ananassa) under the family Rosaceae is widely appreciated, mainly for its characteristic aroma, bright red colour, juicy texture. It is consumed in large quantities, either fresh or in prepared foods, such as preserved fruit juice, pies, ice creams, and milk shakes. Artificial strawberry aroma is also widely used in many industrialized food products. Strawberry is one of the most fascinating fruits of the world, which is a rich source of vitamins and minerals and has fabulous and tantalizing aroma. It contains numerous important dietary components and is rich source of vitamin C (Website. 2004. http://www.dricolls.com/strawberries/nutrition.html). It also contains significant levels of ellagic acid, which is thought to be an anti-carcinogenic (ICAR news, 2005). However, strawberry was introduced in Bangladesh two decades ago and in becoming popular in recent years. Bangladesh Agricultural Research Institute (BARI) recently released a strawberry variety known as BARI Strawberry-1.

\footnotetext{
${ }^{1 \& 3}$ Astt. Professor and M. S Student, respectively, Dept. of Genetic Engineering and Biotechnology, School of Life Sciences, Sylhet University of Science \& Technology (SUST), Sylhet-3114, ${ }^{2}$ Senior Scientific Officer, Horticulture Division, RARS, Bangladesh Agricultural Research Institute (BARI), Hathazari, Chittagong, ${ }^{4}$ Principal Scientific Officer, Biotechnology Division, BARI, Gazipur-1701, ${ }^{5}$ Dept. of Forestry and Environmental Science, SUST, Sylhet-3114, Bangladesh.
} 
Conventional propagation methods are slow, laborious, and expensive with many limitations and may not be recommended for effective and commercial multiplication (Dhar, 1998). Commercial multiplication of the released variety in this country is essential for rapid extension. The advantages of in vitro propagation is that it offers fast multiplication rates (Mott, 1981). Chawla (2002) mentioned the significant advantages of micropropagation by which a large number of plants can be produced from a single individual in a relatively short span of time and space. Keeping in mind the above facts, the present research work was conducted.

\section{Materials and Method}

The experiment was carried out at the Biotechnology Laboratory of BARI, Joydebpur, Gazipur, Bangladesh during March-Septemper 2010. For shoot induction, five BAP concentrations viz., 0.0 (Control), 0.5, 1.0, 1.5, and $2.0 \mathrm{mg} / \mathrm{l}$ and for root induction, four IBA concentrations viz., 0.0 (Control), 0.5, 1.0, and $1.5 \mathrm{mg} / \mathrm{l}$ were used. Both in shoot and root induction experiment, each treatment consisted one test tube and replicated five times and average number of multiple shoots and roots were counted. A nutrient medium for plant regeneration usually consists of organic and inorganic salts, irons, a carbon source, some vitamins and growth regulators. In this study, MS (Murashige and Skoog, 1962) medium was used as basal medium for plant regeneration.

Runner segments and runner tips of BARI Strawberry -1 was used as explant. Explants were collected from Horticulture Research Centre (HRC) of BARI. For establishing the explants in the media, only the tender and actively growing runner segments and runner tips having $1.00-1.25 \mathrm{~cm}$ long were prepared to use as explants. The explants were washed with running tap water and sterilized with trix and $\mathrm{HgCl}_{2}$. To maintain aseptic condition, precautions were taken in every step of works. All inoculations and aseptic manipulations were carried out in a laminar airflow cabinet. During operation, hands and cabinet base were rubbed with $70 \%$ ethyl alcohol frequently for maintaining clean condition. To obtain possible contamination free condition in clean bench, proper care was taken during explant preparation. Shoot tips were prepared inside the laminar airflow cabinet using a fine sterile forcep and scalpel. The excised shoot tips were then inoculated on to the culture test tubes per vials containing various concentrations of BAP for in vitro multiple shoot regeneration. The physical conditions for growth and development of cultures were maintained at the temperature of $25 \pm 1^{\circ} \mathrm{C}$ and a light intensity of 2000-3000 lux provided by fluorescent tube. The photoperiod was maintained at 16 hours light and 8 hours dark (16L/8D) and the relative humidity was $60-70 \%$. 
Successful shoot formation became evident when small green fresh leaves began to emerge. It is the first sign of regeneration. These tiny leaves, when developed in their actual shape were transferred into fresh media containing the same hormonal concentration for further proliferation and development of shoots. First subculture and second subculture were carried out at three and five weeks after shoot initiation, respectively. The regenerated multiple shoots were carefully removed from the test tubes and placed on a sterile hard paper. Each shoot was cut from the basal end and was transferred to new media containing concentrations of BAP for further multiple shoot induction. For root induction, half strength MS media fortified with different IBA concentrations were used.

Data on number of explants cultured, average number of shoots/culture, average length of shoots/culture, average number of shoots per culture, days to root induction, average number of roots per culture and average length of roots/ were recorded. Mean data were calculated to present the statistical information.

\section{Results}

\section{Shoot induction}

Runner segments and tips were cultured in MS media fortified with different BAP concentrations i.e., $0.0 \mathrm{mg} / \mathrm{l}$ (control), $0.5 \mathrm{mg} / 1,1.0 \mathrm{mg} / \mathrm{l}, 1.5 \mathrm{mg} / \mathrm{l}, 2 \mathrm{mg} / \mathrm{l}$ (Fig. 1). After three weeks, the cultured explants were subcultured.

Table 1. Response of strawberry explant to different BAP concentrations supplemented in MS medium on shoot proliferation.

\begin{tabular}{c|c|c|c|c}
\hline BAP (mg/l) & $\begin{array}{c}\text { No. of } \\
\text { explants/culture }\end{array}$ & $\begin{array}{c}\text { Average no. of } \\
\text { shoots/culture }\end{array}$ & $\begin{array}{c}\text { Average length of } \\
\text { shoots/culture }(\mathrm{cm})\end{array}$ & $\begin{array}{c}\text { Average no. of } \\
\text { leaves/culture }\end{array}$ \\
\hline 0.0 & 10 & 2 & 0.57 & 2 \\
0.5 & 10 & 7 & 3.34 & 5 \\
1.0 & 10 & 4 & 2.5 & 3 \\
1.5 & 10 & 2 & 2.0 & 2 \\
2.0 & 10 & 0 & 0.0 & 0.0 \\
\hline
\end{tabular}

The highest average number of shoots (7), length of shoots $(3.34 \mathrm{~cm})$, and leaves (5) were observed at the concentration of $0.5 \mathrm{mg} / \mathrm{l} \mathrm{BAP}$ (Table 1). Fig. 2 showed the multiple shoots of strawberry. No shoot was induced at the highest $(2.0 \mathrm{mg} / \mathrm{l})$ BAP concentration. Rest of the treatments produced multiple shoot which were fragile. The lowest average length $(0.57 \mathrm{~cm})$ of shoot and average number (2) of leaves were observed in BAP free media.

\section{Root induction}

After five weeks, the elongated shoots were transferred into the rooting media. Among the concentrations, IBA @ $0.5 \mathrm{mg} / \mathrm{l}$ showed the best performance in all the parameters studied (Table 2). 
Table 2. Effect of different IBA concentrations in half strength MS medium on root induction ability of strawberry.

\begin{tabular}{c|c|c|c}
\hline $\begin{array}{c}\text { Treatment } \\
\text { IBA(mg/l) }\end{array}$ & Day of root initiation & $\begin{array}{c}\text { Average number of } \\
\text { roots/culture }\end{array}$ & $\begin{array}{c}\text { Average length of } \\
\text { roots/culture }\end{array}$ \\
\hline 0.0 & - & - & - \\
0.5 & $8-10$ & 6 & $3.05 \mathrm{~cm}$ \\
1.0 & $8-10$ & 4 & $2.2 \mathrm{~cm}$ \\
1.5 & $10-12$ & 2 & $1.5 \mathrm{~cm}$ \\
2.0 & $10-12$ & 2 & $1.0 \mathrm{~cm}$ \\
\hline
\end{tabular}

Both 0.5 and $1.0 \mathrm{mg} / \mathrm{l} \mathrm{IBA}$ concentration took the shortest time (8-10 days) for root induction. The highest no. (6) of roots/culture and the longest $(3.05 \mathrm{~cm})$ roots were also obtained from same concentration. On the other hand, root produced by other treatments were narrow. No root were produced in control treatment.

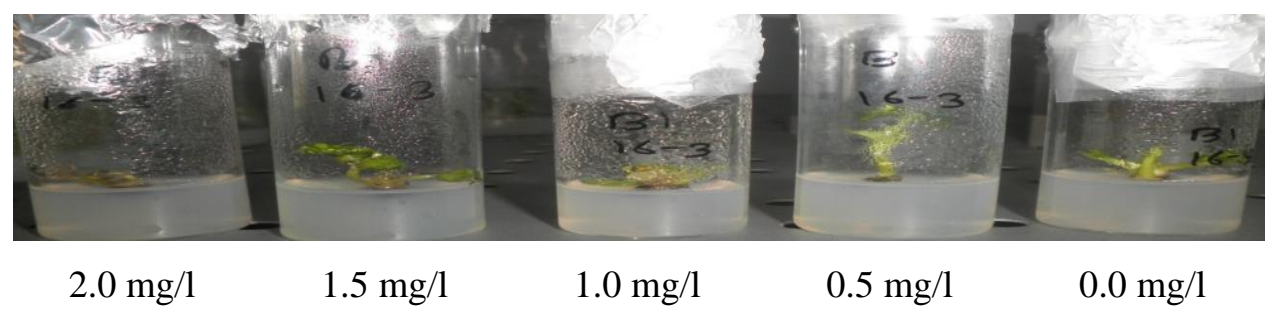

Fig. 1. Shoot proliferation on different BAP concentrations.

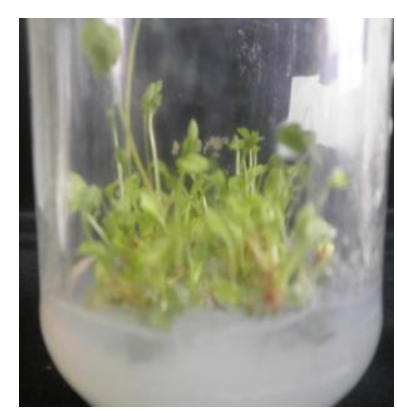

Fig. 2. Multiple shoot was observed at $0.5 \mathrm{mg} / \mathrm{l} \mathrm{BAP}$ concentration.

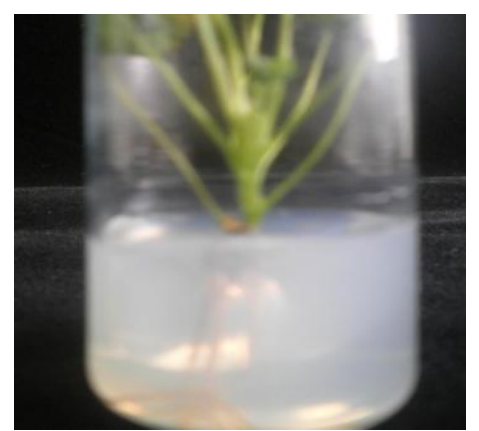

Fig. 3. Root induction was observed at $0.5 \mathrm{mg} / \mathrm{l} \mathrm{IBA}$.

\section{Discussion}

Numerous studies have been published regarding tissue culture of strawberry. Micropropagation of strawberry was reported about 30 years ago (Boxus, 1999). Mahmood et al. (1994) reported in their study that the best shooting response was observed on the media supplemented with $0.5 \mathrm{mg} / \mathrm{l} \mathrm{BAP}$, which was same as 
present finding, while the number of leaves were 8 which was different from present result (i.e., 5 leaves).

Marcotrigiano et al. (1984) studied the effect of BAP on in vitro multiplication of strawberry and observed that lower level of BAP $(0.5 \mathrm{mg} / \mathrm{l})$ was more effective for shoot proliferation as compared to 1.0 to $3.0 \mathrm{mg} / \mathrm{l} \mathrm{BAP}$. Same results was also observed at higher BAP concentration $(2.0 \mathrm{mg} / \mathrm{l})$ in the present study. Variations was also observed in growth stage of plantlets at different BAP levels.

Maliaricikova and Mokra (1986) observed root formation within 3 - 4 weeks after plantlets inoculation in rooting media. Asahira and Kano (1977) also obtained the same results. These results did not show similarities with present results as root formation was observed within 2 weeks of plantlet inoculation. No rooting was observed in auxin free media and the best response of root formation was observed at $0.5 \mathrm{mg} / \mathrm{l} \mathrm{IBA}$ enriched media (Fig. 3). In this investigation, a micropropagation protocol for strawberry has been developed. On the other hand, this finding could be utilized in plant genetic transformation studies for better improvement.

\section{Acknowledgements}

The authors are grateful to Biotechnology Division of BARI for providing research facilities to carry out this work at their lab.

\section{References}

Asahira, T. And Y. Kano. 1977. Shoot formation from cultured tissue of strawberry fruits. J. Jap. Soc. Hort. Sci. 46 (3): 317-324

Boxus, P. 1999. Micropropagation of strawberry via axillary shoot proliferation. In: Plant Cell Culture Protocols. Methods in Molecular Biology. Part III. Plant Propagation In vitro. Hall R. D. (ed.) Humana Press Inc., Totowa NJ 111: 103-114

Chawla, H. S. 2002. Introduction to Plant Biotechnology. Oxford \& IBH publishing Co. Pvt. Ltd., 66 Janapath, New Delhi 110001, India. P. 39

Dhar, M. 1998. Techniques of vegetative and in vitro propagation of Jackffilit. Ph.D. Thesis, Banggabandhu Shaikh Mujibar Rahman Agricultural University, Salna, Gazipur, Bangladesh, $120 \mathrm{Pp}$.

ICAR News, October-December 2005. Indian council of agriculture research, Vol 11, no. 4, New Delhi, India

Maliaricikova, V. and A. Mokra. 1986. Clonal propagation of strawberry in vitro. Ved. Pra. Vyskum. Usta. Ovecny. Okrasn. Dre Boj. 6: 117-123

Marcotrigiano, M., H.J. Swartz, S.E. Gray, D.Tokaricky and J. Popenoe. 1984. The effect of benzylaminopurine on the in vitro multiplication rate and subsequent field 
performance of tissue culture propagation strawberry plant. Adv. Strawberry Prod. 3 (Spring): 23-25

Mott, R. L. 1981. Trees, In: Conger, B.V. (ed.), Cloning Agricultural Plants via in vitro Techniques. CRC Press, Boca Ratan. Pp. 217-254.

Murashige, T. and F. Skoog. 1962. A revised medium for rapid growth and bioassays with tobacco tissue cultures. Physiol. Plant 15: 473-497.

Mahmood, S., H. Rashid, A. Quraishi, N. Iqbal, S.S. Arjumand. 1994. Clonal propagation of strawberry through tissue culture. Pakistan J. Agric Res. vol. 15 No. 1.

Website. 2004. http://www.dricolls.com/strawberries/nutrition.html. 